\title{
Satisfaction with the Decision to Become a Lawyer: The Implications for Diversity in the Legal Profession
}

\author{
Yonghong Jade Xu \\ College of Education, University of Memphis \\ Ball Hall 100, University of Memphis, Memphis, TN 38152 \\ E-mail: yxu@memphis.edu
}

This material is based upon work supported by Access Group and the Association for Institutional Research. Any opinions, findings, and conclusions or recommendations expressed in this material are those of the author(s) and do not necessarily reflect the views of Access Group or the Association for Institutional Research.

\section{Abstract}

This study is conducted in response to the national attention to the underrepresentation of women and minorities in the legal profession and judicial systems. In order to better understand the work experiences of women and minorities, data from a longitudinal national survey, After the JD (AJD) Study, are used to examine individuals' satisfaction with their decision to become lawyers through the lens of Bourdieu's theorization of cultural, social, and economic capitals. The goal is to understand how the underrepresentation of women and minorities was related to their career progress within the structural norms of the legal practice through a comparison with their White male counterparts. The results indicated satisfaction with a legal career depends on individuals' social origins and the credentials related to the origins, and also on the extent to which the possibilities and potentials produced by the professional career meet the individuals' expectations. The findings revealed that women and minority lawyers reported similar levels of satisfaction with their decision to enter the legal profession in comparison to their White male counterparts, and presented a challenge to the well-accepted argument that women and racial minorities are underrepresented in legal professions partly due to their low satisfaction and the conscious choices to opt out of their investments in and commitments to a legal career. It is hoped that this study can stimulate further examinations of the structural and organizational practices of the legal profession and promote equal opportunities for women and minorities in the legal profession.

Keywords: Career satisfaction, legal professional, gender and racial inequalities

DOI: $10.7176 / \mathrm{JEP} / 12-18-05$

Publication date:June $30^{\text {th }} 2021$

\section{Introduction}

Gender- and race-related inequalities have been pervasive in the U.S. labor market. Over the years, a large number of studies have confirmed gender- and race-related segregation and wage differences in the general labor market (Joy, 2000; Oaxaca, 1973; Toutkoushian \& Conely, 2005; Umbach, 2007). However, limited empirical research is available investigating the specific reasons leading to the attrition of women and minorities in the pipeline of law professions. This limited attention is particularly disturbing given that national statistics demonstrate a reality that neither women nor minorities have sufficiently represented in the legal profession. Women and racial minorities account for roughly $35 \%$ and $9 \%$, respectively, of over 1,300,000 licensed lawyers nationally, (ABA, 2015), which is in stark contrast to the fact that they represent $50 \%$ and $32 \%$ of the U.S. population (U.S. Census Bureau, 2014). In addition, both groups are distributed disproportionately in less prestigious positions and earn less than their white male counterparts.

There are various and intervening factors that lead the lack of diversity in legal education and profession. This study focuses on the factors that lead to career satisfaction and how they may contribute to a better understanding of diversity from a psychological perspective. Extant literature (e.g., Kay et al., 2013; Kornhauser and Revesz, 2000; Mobley 1982; Steers \& Mowday 1981) provides consistent support that individual subjective evaluation of income, job responsibility, work condition, and participation in decision-making lead to varying degrees of satisfaction with professional progress, which in turn influence their career-related decisions and long-term professional trajectories (Dinovitzer \& Garth, 2007; Kay 1997; Kay \& Hagan 2003; Wilkins \& Gulati 1996). Nonetheless, personal expectations, conditioned by individuals' social, cultural, and economic upbringings, may also influence job satisfaction and professional choices. Therefore, in this study, individuals' satisfaction with their decision to become lawyers is examined longitudinally in the context of their professional experiences at work, controlling for demographic and socioeconomic characteristics, in order to gain a better understanding of the factors leading to the underrepresentation of women and minorities in the legal profession.

\section{Review of Literature}

2.1 Gender/racial disparities in the legal profession

Part of the literature and most social media often discuss lawyers' satisfaction with a focus on the relative 
dissatisfaction of women and minority lawyers (e.g., Rhode 2000; see also Dinovitzer \& Garth, 2007). In general, the perception is that women lawyers are dissatisfied with their career, and this perception of dissatisfaction is reinforced by empirical findings in an array of studies reporting that 1) women are much more likely than men to be unemployed or to work part-time after earning a law degree (Tamanaha, 2013); 2) for those having full-time positions in law firms, women lawyers do not achieve professional success accorded to their male colleagues, even when they have comparable human capital investment to the same extent as their male counterparts (Hagan \& Kay, Mossman, 2005); 3) women are more likely to be in positions of lower earning and less promotion opportunities, and their projected earnings in the legal profession being $25 \%$ lower than men because of pay differentials and other career-related factors, and 4) women at large firms were significantly less likely to be promoted to partner and leave their jobs a higher rate than men (Dinovitzer \& Garth, 2007; Kornhauser \& Revesz, 2000; Patterson \& Maven, 2009).

The status of racial minorities in the legal profession is more dismal. Despite efforts to diversify the profession, racial and ethnic minorities represent less than $15 \%$ of all lawyers in the U.S., which is consistent with recent reports that racial and ethnic groups are vastly underrepresented in law schools and the legal profession in America (CAIS Scorecard, 2012). Notwithstanding the severe inequality, studies concerning racial diversity have remained scarce and mostly anecdotal. Although very limited, research on minorities in the legal profession found that the experiences of racial minority and women lawyers bear notable similarities (PaynePikus et al., 2010); First, both groups are overrepresented in positions of lower earning and experience reduced promotion prospects (Kay et al., 2013; Kornhauser \& Revesz, 2000). Second, both groups often face major challenges associated with biases, traditional stereotypes, and marginalization (Nance \& Madsen, 2014). Third, studies have found higher rates of mobility among women (Kay 1997; Kay \& Hagan 2003; Sommerlad \& Sanderson 1998) and minorities (Heinz et al. 2005; Wilkins \& Gulati 1996) as a consequence of their low job satisfaction. Unfortunately, job changes carry high costs for the individuals and are likely to impact their professional trajectories negatively in the long run.

\subsection{Job satisfaction and related factors}

Extant literature offers evidence concerning the relationship between important structural features of legal practice and individuals' job satisfaction (Dinovitzer \& Garth, 2007). For instance, income has been found to be a positive predictor of high job satisfaction (Heinz et al. 2005; Hagan \& Kay;1995), even though this relationship may not be consistent, especially for lawyers working in private practice in large corporate firms (Dau-Schmidt \& Mukhopadhaya, 1999). Additionally, job satisfaction has been found to be higher for lawyers who had mentors (Mobley et al. 1994). Therefore, women and minorities, with lower earnings and more frequent encounters with biases and isolation, are believed to be less satisfied in their job than their White male counterparts (Rhode, 2000). Inconsistent with this perception, however, a number of empirical studies have found that lawyers are relatively satisfied with their job (Dinovitzer \& Garth, 2007; Gellis 1991; Heinz et al. 2005) regardless of gender and/or race (Hagan \& Kay 1995, Dau-Schmidt \& Mukhopadhaya, 1999; Lempert et al., 2000).

In order to make sense of the contradictory notions about job satisfaction in the legal profession, Dinovitzer and Garth (2007) offered a hypothesis from a "Bourdieusian" perspective. They argued that social and cultural origins shape individuals' expectations, including their career expectations and aspirations. That is, individuals acquire a set of practices and values through living life and internalize what they can and cannot reasonably expect in life (Calhoun 2003). As such, job satisfaction is intimately linked to what individuals seek to obtain from their jobs, rather than it simply being inculcated through the job settings (Dinovitzer \& Garth, 2007). They further posited that law school is the key site within which students' expectations and aspirations develop. For individuals from less advantaged social backgrounds, gaining entry to the legal profession is a rewarding path leading to highly desired independence and autonomy; but for individuals from upper social classes, the prestige of the law school they attend is itself a function of their social status, such that choices of educational paths and law programs simply confirm and reaffirm nothing more than their expectations (Bourdieu 1998; Dinovitzer \& Garth, 2007). Job and career satisfaction in the legal profession, thus, is largely shaped by individuals' social background and a match or mismatch between expectations and circumstances, which explain their findings that students from the most elite law schools are the least satisfied with their career choice, whereas graduates from lower ranked institutions express high levels of career satisfaction.

\subsection{Job Satisfaction and Career Satisfaction}

Another caveat, though not commonly discussed in the literature, is the difference between job satisfaction and career satisfaction. For example, an individual may feel positive about choosing a legal career, yet feel dissatisfied at a particular job due to specific organizational attributes that lead to unfulfilled needs for challenge, achievement, and professional status (Kay et al., 2013). Job satisfaction is a short-term perception about personal fit with the job settings of a particular employment. Dissatisfaction with a job can be eliminated by changing to a 
job of better fit in the same profession.

In comparison, satisfaction with a career choice warrants a more comprehensive interpretation. Although satisfaction with the legal career may be impacted by satisfaction at a given job, it is not contingent upon getting a particular job. Rather career satisfaction depends more on individuals' social origins and the credentials related to the origins as well as on the extent to which the possibilities produced by the professional career meet the individuals' expectations in the long run (Dinovitzer \& Garth, 2007; Dinovitzer et al., 2013). Evidence suggests that, for both women and minorities, low job satisfaction often increases their likelihood of leaving their jobs and even leaving the profession all together (Dinovitzer \& Garth, 2007).

\section{Theoretically Framework}

In this study, individuals' satisfaction with their legal career is examined longitudinally through the lens of Bourdieu's theorization of cultural, social, and economic capitals. The goal is to investigate how women and minorities evaluate their career progress differently from their White male counterparts within the structural norms of the legal practice, controlling for differences in social and cultural backgrounds. Bourdieu's theorization of cultural, social, and economic capitals has been widely adopted in the educational and sociological literature.

\subsection{Cultural capital.}

Cultural capital is the totality of an individual's cultural background and parent-related factors that define one's class status (Xu, 2013). It refers to the heritage, knowledge, and trait an individual possesses in order to compete in a society dominated by the values of the majority (Bourdieu \& Passeron, 1977). According to Bourdieu, individuals' cultural capital is converted into educational credentials, and ultimately occupational success (Goyette \& Mullen, 2006), accumulation of social capital (Bourdieu \& Passeron, 1977), and career attainment (Stoecker \& Pascarella, 1991).

\subsection{Social capital.}

Social capital is "the aggregate of the actual or potential resources which are linked to possession of a durable network." (Bourdieu, 1986). Social capital is essential to the legal profession because the practice of law is organized around networks (Patton, 2005). Since relationships are the key to performance, both inside and outside the firm, social capital must be taken seriously in studies of the legal profession. Social capital increases individuals' ability to draw on relationship networks for establishing or expanding support (Sterling \& Reichman, 2013). However, women and minority lawyers continue to report a hostile social environment and have difficulties integrating (Reynoso \& Amron, 2002).

\subsection{Economic capital.}

Economic captial refers to financial resources and physical materials that are directly convertible into money. It is critical to understand the role of economic capital in the systems of legal education and profession given the high cost of law education. High tuition and the resulting debt in legal education have increased economic pressure and lowered opportunities for individuals from low-SES backgrounds, the vast majority of whom are racial minorities (Morrissey, 2006). Additionally, high debts may negatively impact women and minorities' valuation of the legal profession given the dismal reality that they are distributed disproportionately in less prestigious positions and have lower earnings than their White male counterparts (Reynoso \& Amron, 2002).

\subsection{Human capital}

In addition, given the importance of law school rankings in the legal job market, Human capital theory (HCT) is added to the theoretical framework of this study. HCT is probably the dominant framework in diversity studies of the legal profession (e.g., Kay \& Hagan, 2008; Payne-Pikus et al., 2010). HCT is a neoclassical economic theory that views individuals as rational actors who make educational and occupational decisions based upon a calculation of associated monetary costs and benefits (Melguizo, 2011; Xu, 2015). This perspective regards educational choices (e.g., types of law school) and employment experiences (e.g., type of employer, fulltime/part-time status) as investments, and explains differences in earnings and status attainment as rewards for productivity (Becker, 1964; Kay \& Hagan, 2008). It is important to note that even though education and skill investments are useful for predicting earning and professional status, empirical research has repeatedly shown that women obtain lower returns for the same investments in human capital than do men (Dinovitzer et al., 2009; $\mathrm{Xu}, 2015)$.

\section{Research Questions}

Cultural, social, economic, and human capitals are interconnected and their functions in individuals' professional and career development are conditioned by the residing structural context and dominant organizational norms. In 
Bourdieu's conception, there are important connections between social structure and different forms of personal capital; however, little attention has been given to how various factors in combination influence the experiences of women and minorities in the legal profession. To fill this gap, the present study seeks to answer two research questions:

1) What factors impact individuals' satisfaction with their decision to become lawyers? Specifically, are there differences between women and men? Between White and minorities?

2) How has individuals' satisfaction with their decision to become lawyers changed over a ten-year span as they progress from career entry?

Answers to these research questions will provide a better understanding of the potential factors underlying the underrepresentation of women and minorities in the legal profession and can suggest approaches to improve diversity in the future.

\section{Methods}

\subsection{Data Source}

Data from a longitudinal national survey, After the JD (AJD) Study, are used to investigate how law graduates' satisfaction with their decision to pursue a legal career changed over a ten- year span after graduation. AJD is the first national survey of law graduates in the U.S. The initial sample consisted of over 10 percent of all individuals who were admitted to the bar in 2000 (Dinovitzer et al., 2004) and was considered as being representative of the national population of lawyers who graduated from law school during the time period from June, 1998 to July, 2000. There was an oversampling of 1,465 new lawyers from minority groups (African American, Hispanic, and Asian American). The first wave (AJD1) of data was collected in May, 2002 and was completed with a response rate of $71 \%$, resulting in a total of 4,538 valid responses. The data collection "provided a snapshot of the personal lives and careers of this cohort about three years after they began practicing law" (ICPSR, 2014). A second wave (AJD2) was designed to follow up after approximately seven years in practice, and the third and last wave of data collection (AJD3) took place in 2012 from individuals who had previously responded to either AJD1 or AJD2 (ICPSR, 2014).

In all three waves, the sampling design used a two-stage process. The first stage was to divide the nation into eighteen strata by region and size of the new lawyer population, after which one primary sampling unit (PSU) was chosen from each stratum. During the second stage, individual lawyers were sampled from the PSUs based on a design that would lead to a weighted sample representative of the national population. Additional examination of data provided evidence that the gender and racial compositions of the sample closely matched with data published by the ABA and the 2000 U.S. Census (Dinovitzer \& Garth, 2007). The survey instrument included questions about the respondent's law school education, job history and search process; the nature of the current job, and job satisfaction; and a variety of background and contextual information.

In the present study, data were weighted in both the descriptive and inferential statistical analyses. Missing data were imputed using regression when related measures could be identified. Some missing information (e.g., parents' education) may lead to reduction in sample size for the regression analysis. The sample sizes are reported in Table 1 for the three waves after data preparation.

\subsection{Variables}

Respondents' self-reported satisfactions with their decision to enter the legal profession in the three waves of data collection were the dependent variables in the multiple regression analysis. This variable was measured by a single question "How satisfied are you with your decision to become a lawyer?", with the response coded as "1" for "extremely dissatisfied" to " 5 " for "extremely satisfied" on a Likert scale. Since satisfaction with the legal profession can be influenced by many factors in the cultural, social, economic, and organizational dimensions, the following variables were included as the independent variables:

1) Cultural capital, which was measured by race/ethnicity, parents born in the U.S., and highest educational attainment of parents. Because of the extremely low number of participants from certain racial groups, race was dichotomously coded into White vs. minorities.

2) Due to the lack of direct measures, social capital was captured by several proxies, including whether the respondent actively participated in organizational activities in law school (wave 1), the level of social participation in 2007 (wave 2) and 2012 (wave 3), and the number of mentors and types of support provided by mentors (when available).

3) Economic capital, which was quantified by total law school education loan amount, and percentage of funding from personal resources.

4) Since all respondents have a law school degree, their differences in human capital investment were measured by the ranking of the law school attended and personal evaluation about the importance of past experiences in legal services toward obtaining the first employment.

5) Demographic information included gender, age, marital status, and number of children. 
6) Structural experience, which was captured by the type of position (part-time/full-time, practicing lawyer) held, whether s/he experienced discrimination at work, and self-reported job satisfaction as a total of 16 items concerning job security, compensation, autonomy, performance evaluation, and advancement opportunity.

In addition, the number of job offers received from public and private sectors at the time of graduation and annual income were included because studies (e.g., Tamanaha, 2013) have shown that the initial job a graduate obtains has career-determining consequences. Those who obtain private corporate positions tend to remain on the higher earning track serving institutional clients, whereas those who do not initially obtain these positions tend to serve individual clients and occupy lower paid government positions.

\subsection{Analytical Procedures}

Descriptive statistics was first presented to offer an overview of gender and racial differences in the major measures used in the study. To answer the research questions, linear multiple regression models were constructed for each of the three waves of AJD data collection. The individual models used respondents' selfreported satisfactions with their decision to enter the legal profession at Waves 1, 2, and 3 as the dependent variables, respectively. The models shared the measures on demographic variables, but have updated information on job related measures. In addition, the model for Wave 1 included several variables concerning respondents' job search after graduation (e.g., number of job offers), whereas the models for Waves 2 and 3 had variables related to mentors and social participation. Consistencies and differences in the regression models of the three waves of data make it possible to identify factors impacting individuals' satisfaction with a legal career and track underlying changes over a ten-year span, beginning from career entry.

\section{Results}

Descriptive information presented in Table 1 shows that the weighted sample sizes were 4,281, 3,682, and 2,946 in the three waves, respectively. The percentages of women remained relatively steady with a slight trend to decrease from $46.6 \%$ in 2002 to $45.5 \%$ to 2012 , whereas the percentages of racial minority increased from $18.4 \%$ to $20.5 \%$ during the same period. Comparisons among the four groups indicated that minorities, minority women in particular, had significantly higher amounts of educational loan after completing law school (p $<.001)$. Also, the average ranking of law schools attended by minority students appeared to be higher than that of White graduates, but the difference was statistically nonsignificant $(p>.05)$. During the first seven years of a legal career, there was a significant drop in the percentage of women being practicing lawyers $(\mathrm{p}<.001)$, especially for White females (from $84 \%$ to $73 \%$ ). Twelve years after graduation, men were much more likely to be married $(\mathrm{p}<.001)$ than their women counterparts who reported a significantly more number of children.

The data also confirmed the general patterns suggested by the literature. Female lawyers earnings were significantly lower $(\mathrm{p}<.001)$ than male lawyers from career entry, and the gap increased overtime. Furthermore, twelve years after graduation, the percentage of women having gained partnership in law firms was significantly lower than that of their male counterparts. In all three waves of data collection, minority legal professionals reported significantly higher satisfaction with a legal career than their White colleagues $(\mathrm{p}<.001)$; men tend to report more satisfaction than women with their decision to become a lawyer, but the difference was statistically nonsignificant.

The multiple regression models are presented in Table 2. The first two models were constructed for data collected at ADJ waves 1 and 2. Because both models indicated that there was a significant difference in satisfaction with a legal career between White and minority lawyers $(p<.001)$, two more regression models of identical structure were constructed for wave 3, one for White and the other for minorities, in order to further examine racial differences and uncover possible interactions between race and other independent variables. As expected, satisfaction with choosing a legal career was significantly related to job satisfaction $(p<.001)$ in all three waves. Satisfaction with choosing a legal career was also positively related to individuals' annual income $(\mathrm{p}<.001)$, but this positive association did not hold for minority legal professionals. Another consistent pattern found was that those who graduated from law schools of higher ranks tended to be less satisfied with their legal career, but the magnitude of the dissatisfaction reduced over time and became statistically nonsignificant at wave 3. Although women had significantly lower income, their satisfaction with having a legal career was at a comparable level with male lawyers, controlling for individual differences in social, cultural, and economic capitals.

At career entry, more active participation in social organizations during law school was positively related to the satisfaction with choosing the legal profession $(\beta=0.045, \mathrm{p}<.01)$. At later times, having mentors was positively related to the decision to become a lawyer regardless of background differences. That said, lawyers of racial minorities reported higher levels of participation in social activities and organizations when they felt more satisfied with their career choice ten years into the legal profession $(\beta=0.126, p<.001)$. Comparisons between Models 3 and 4 further revealed that, for Caucasian lawyers, coming from a family background where both 
parents were U.S.-born $(\beta=0.067, \mathrm{p}<.001)$ and having a full-time employment status $(\beta=0.089, \mathrm{p}<.01)$ were the two factors contributing positively to satisfaction with a legal career. On the other hand, for racial minorities, being a practicing lawyer contributed significantly to greater satisfaction with a legal career $(\beta=0.180, p<.001)$. Finally, it is worth noting that Caucasian lawyers, but not racial minority professionals, reported significantly lower satisfaction with being in the legal profession when discrimination was experienced at work $(\beta=-0.083, p$ $<.001)$.

\section{Discussion}

Using a longitudinal national data set, this study examined what factors contributed to law school graduates' satisfaction with their decision to become lawyers, with a focus on understanding gender- and race-related differences in their satisfaction with a legal career. The results indicated that satisfaction with the legal career was influenced by cultural, social, economic and human capital of the individuals, as well as structural aspects experienced at work. Nonetheless, results suggested that the effects of these factors may change over time, as discussed in detail below.

\subsection{The roles of cultural, socioeconomic, and human capital in career satisfaction}

The ranking of law school, as a measure of human capital, was negatively related to satisfaction with the decision to enter the legal profession; however, this negative relationship grew weaker overtime and became statistically nonsignificant twelve years after career entry. This negative relationship is explainable from the "Bourdieusian" perspective, given the fact that an overwhelming majority of elite law school graduates come from very affluent family backgrounds that provide advantageous social access (Dinovitzer \& Garth, 2007). According to Dinovitzer and Garth (2007), these individuals from upper social classes expect to be given a position within the elite and are more likely to be unhappy about their work, either because it did not comport with their image of where they belong or because they believed they deserved better treatment than what they were given at work (Bourdieu 1998; Dinovitzer \& Garth, 2007). In contrast, graduates of lower tier law schools started with relatively low career expectations. To them, entry to the legal profession opens the door to upward mobility from their modest background. In sum, the prestige of law school simply reinforced the different expectations and aspirations of students from various socioeconomic origins. The weakened relationship twelve years later may be attributable to the changes in personal expectations and gradual acceptance of reality overtime.

Having U.S.-born parents, as a proxy of cultural capital, was related to greater satisfaction with choosing a legal career for law school graduates, and this pattern appeared to be much stronger for Caucasians according to the wave 3 of the AJD data collection. It may be speculated that individuals with U.S.-born parents may value the legal profession more as a confirmation of social status than those with a foreign background. However, the question arises as to why this pattern not observed for racial minorities. It is possible that, because racial minorities are more likely to be from a lower socioeconomic background (Morrissey, 2006), the impact of cultural capital on their career satisfaction was cancelled out by differences in socioeconomic status. Such speculations must be verified with additional evidence as they cannot be confirmed through the current study.

With limited information in the data set, one proxy of social capital in this study was individuals' participation in social organizations in law school (wave 1) and their social participation in legal and civic organizations and the number of mentors after graduation (waves 2 and 3). Social participation was related to greater satisfaction with choosing a legal profession at the time of career entry, but the opposite was found seven years later for the cohort of lawyers. Another five years later, the positive relationship between level of social participation and satisfaction with career choice reappeared, but for lawyers of racial minorities only. The inconstancy may be related to the fact that additional measures of mentors were included in later models. Consistent with the findings in the literature, availability of mentors was positively related to the decision to become a lawyer regardless of background differences. Overall, the findings suggest a positive relationship between social capital and satisfaction with the legal career. From the perspective of Bourdieu's (1998) social capital, individuals who are well-socialized in the profession have the advantage of gaining a better "feel for the game" (p. 79); they are more likely to succeed at work because they are well-informed about what they should be investing in and how to prepare themselves for future opportunities. In other words, the sense of being a master of the "game" leads to greater satisfaction with being a lawyer.

The amount of debt resulted from law education was the only measure of economic capital found to be related to satisfaction with a legal career. The higher the debt, the lower the satisfaction, and this negative relationship was the strongest at wave 2 , seven years into the legal profession. The negative relationship is not surprising given that there is a drastic increase in the percentage of law graduates bearing student debt (Kay et al., 2013). Individuals may feel that their investment in law education was a bad decision when they struggle to pay off a large amount of student debt, with a so-called "buyers' remorse" leading to reduced satisfaction with their career of choice. 


\subsection{Structural factors and career satisfaction}

As expected, lawyers who felt more satisfied with their current jobs reported greater satisfaction with choosing a legal career. Income is another factor positively related to career satisfaction with one exception: racial minorities did not feel that their satisfaction with being a lawyer was related to income after twelve years in the profession. Rather, the career satisfaction was much higher for minority individuals who were practicing lawyers. Another difference between White and racial minority lawyers is related to experiences of discrimination. Experiences of discrimination at work significantly reduced the level of career satisfaction for White lawyers, but the same pattern was not observed for racial minorities based on wave 3 of the AJD data. This difference may, again, be explained by the discrepancies between what individuals expected and what they experienced. Knowing the traditional White dominant organizational culture in the legal profession, minority lawyers who anticipated facing biases and isolation may have greater resilience against discrimination. As such, discrimination experienced at work may have not been given power to impact how they felt about their choice of a legal career. On the other hand White lawyers likely do not begin their career with such expectations; thus, their career satisfaction may be more likely to be damaged thorugh experiences of discrimination or injustice in the profession.

\subsection{Gender-and race-related differences in legal career satisfaction}

The results confirmed that women's income was significantly lower than that of male lawyers at career entry with the gap increasing overtime. Women also demonstrated a higher attrition rate from being practicing lawyers; for those who persisted, the percentage of women who gained partnership in law firms was significantly lower than their male counterparts. Despite all the disadvantages for women, no significant difference was found between genders in their reported satisfaction with the decision to enter the legal profession during the first decade of a legal career. Further, minority legal professionals reported significantly higher career satisfaction than their White colleagues, although different factors contributed to their overall career satisfaction as discussed in previous sections.

Extant literature suggests that women are more likely to leave law practice than men, without clarity concerning factors affecting women's to decision to exit their positions (Sterling and Reichman, 2013). With the finding that lawyers are relatively satisfied in their legal professions - and notably that women and minorities are not less satisfied than the White male counterparts - this study calls into question the argument that disparities in the legal profession and gender/racial differences in outcomes are the result of free and voluntary choices of women and minorities to opt out of their investments and commitments to the legal profession (Payne-Pikus et al., 2010). There is ample evidence demonstrating that gender and racial inequalities result from a combination of individual, structural, and organizational attributes (Kay \& Hagan, 1998; Xu, 2015). Findings from this study suggest that the structural and organizational norms of the legal profession should be further investigated to better understand their function in the persistent underrepresentation of women and minorities.

Furthermore, satisfaction with entering the legal profession is an expression of the subjective evaluation of career values relative to individuals' background origin and credentials. The comparative level of career satisfaction of women and minority lawyers with those of White males may be an indication of their modest expectations at the time entering the profession. With low expectations but similar levels of investment in law education, women and minority lawyers may be more resilient against adverse work environments. It is difficult to deny the lack of equal opportunities as being partly responsible for the low presence of women and minorities in the legal profession. Future research is necessary to examine the common practices of hiring, promotion, performance evaluation, and compensations in the legal profession, to identify and correct potential factors that lead to unequal treatments of female and/or racial minorities at all levels of the legal pipeline.

\section{4 Limitations}

First, the data used in this study was collected in 2002, and the experiences of women and minority lawyers may have changed in the past fifteen years. However, the AJD is the first national survey of law graduates in the U.S. that offered comprehensive information and made this study possible. Replication of this study with more recent data, when available, is desirable in order to benchmark progress of diversity in the legal profession. Second, in some places, proxy measures of social, cultural, economic, and human capital were used due to limited information in the AJD data set. For instance, a direct measure of parent/family income was lacking, and thus was replaced by percentage of funding for law education from personal resources. The use of proxies may underestimate the impact of certain variables; however, it was inevitable given the guiding theoretical framework. Third, all racial/ethnic minorities were grouped together for the purpose of comparison with the large group of Caucasian lawyers. The grouping was necessary in order to meet the sample size requirement of multiple regression. It is worth mentioning, however, that because individuals from different minority groups may have distinctive experiences, it would be more informative to examine them separately when sufficient data are available. Finally, the regression models explained roughly $20 \%$ of the variances in career satisfaction, which 
suggest that there may be other factors related to career satisfaction unaccounted for in the models. Future studies using both qualitative quantitative methods may add depth to our understanding about career satisfaction and what factors impact the experiences of women and minorities in the legal profession.

\section{5 Future Research Directions}

Factors contributing to gender and racial inequalities in the legal profession are complex and intertwined. This study provides insight into the cultural, social, and economic conditions that influence individuals' career satisfaction. It is hoped that this study can stimulate further examination of the structural and organizational elements of the legal profession. More research analyzing empirical evidence is needed in order to better guide future practice and improve equal opportunities for women and minority lawyers.

\section{Conclusions}

Findings of this study suggest that women and minority lawyers reported similar levels of satisfaction with their decision to enter the legal profession in comparison to their White male counterparts. It provides further support that women and racial minorities have no motive to opt out of their investments in and commitments to a legal career based on their conscious choices. Gender and racial disparities are the common traits of occupations in which organizational norms are defined and structured in ways that put a premium on the value of majority (e.g., male-dominated, family-exclusive work culture; organizational structures that marginalize and stereotype minorities). Efforts to increase diversity in the legal profession will not only bring equity to more professions in the long run, but will also "elevate historically underserved communities and thereby contribute to the strength of the nation's economic and social life." (Reynoso \& Amron, 2002).

\section{References}

American Bar Association (2015). Lawyer demographics table. Retrieved from http://www.americanbar.org/content/dam/aba/administrative/market research/lawyer-demographics-tables2015. authcheckdam.pdf

American Bar Association (2015). AJD Data Access: Application Procedure. Retrieved from http://www.americanbarfoundation.org/uploads/cms/documents/ajdrestricted_data_contract_august_2015.p df.

Becker, G. S. (1964). Human capital: A theoretical and empirical analysis with special reference to education. New York, NY: National Bureau of Economic Research.

Beckman, C. M. \& Phillips, D. J. (2005). Interorganizational determinants of promotion: Client leadership and the promotion of women attorneys. American Sociological Review, 70, 678-701.

Bourdieu, P. \& Passeron, J. C. (1977). The inheritors: French students and their relation to culture. (R. Nice, Trans.). Chicago, IL: University of Chicago Press.

Bourdieu, P. (1986). The forms of capital. In J. G. Richardson (ed.), Handbook of theory and research for the sociology of education (pp. 241-258). New York, NY: Greenwood Press.

Consortium for Political and Social Research (2014). After the JD, Wave 3: A Longitudinal Study of Careers in Transition, 2012-2013, United States (ICPSR 35480). Retrieved from http://www.icpsr.umich.edu/icpsrweb/ICPSR/studies/35480

Dinovitzer, R. \& Garth, B. G. (2007). Lawyer satisfaction in the process of structuring legal careers. Law \& Society Review, 41(1), 1-49.

Dinovitzer, R., Reichman, N., \& Sterling, J. (2009). The differential valuation of women's work: A new look at the gender gap in lawyers' incomes. Social Forces, 88(2), 819-864.

Ehrenburg, R. G. (2013). American Law Schools in a Time of Transition. Journal of Legal Education, 63(1), 98112.

Goyette, K. A. \& Mullen, A. L. (2006). Who studies the arts and sciences? Social background and the choice and consequences of undergraduate field of study. The Journal of Higher Education, 77(3), 497-538.

Griffith, A. L. (2010). Persistence of women and minorities in the STEM field majors: Is it the school that matters? Economics of Education Review, 29, 911-922.

Huber, J. (1997). Rational choice models in sociology. The American Sociologist, 28(2), 42-53.

Lempert, R. O., Chambers, D. L., \& Adams, T. K. (2000). Michigan's minority graduates in practice: The river runs through law school. Law \& Social Inquiry, 25(2), 395-505.

Melguizo, T. (2011). The review of the theories developed to describe the process of college persistence and attainment. In J. C. Smart \& M. B. Paulsen (eds.), Higher education: Handbook of theory (pp. 395-424). Dordrecht, South Holland: Springer.

Morrissey, D. J. (2006). Saving legal education. Journal of Legal Education, 56, 254-280.

Kay, F. M. \& Hagan, J. (1998). Raising the bar: The gender stratification of law-firm capital. American Sociological Review, 63(5), 728-743. 
Kornhauser, L. A. \& Revesz, R. L. (2000). Legal education and entry into the legal profession: The role of race, gender, and educational debt. New York University Law Review, 829 -964.

Lincoln, Y. S. \& Guba, E. G. (1985). Naturalistic inquiry. New York, NY: Sage.

Olivas, M. A. (2010). Law school admissions after Grutter: Student bodies, pipeline theory, and the river. Journal of Legal Education, 55, 16-27.

Payne-Pikus, M. R., Hagan, J., \& Nelson, R. L. (2010). Experiencing discrimination: Race and retention in America's largest law firms. Law \& Society Review, 44, 553-584.

Patton, P. A. (2005). Women lawyers, their status, influence, and retention in the legal profession. William \& Mary Journal of Women and the Law, 11(2), 173-194.

Reynoso, C. \& Amron, C. (2002). Diversity in legal education: A broader view, a deeper commitment. Journal of Legal Education, 52, 491-505.

Rhode, D. L. (2000) In the Interests of Justice: Reforming the Legal Profession. New York: Oxford Univ. Press.

Robbins, R. L. \& Matthews, T. J. (2014). Cultural diversity: Is it present in American law schools and the legal profession? Journal of Diversity Management, 9(1), 75-82.

Sterling, J. C. \& Reichman, (2013). Navigating the gap: Reflections on 20 years researching gender disparities in the legal profession. Florida International Law Review, 8(2), 515-539.

Stoecker, J. L. \& Pascarella, E. T. (1991). Women's college and women's career attainments revisited. Journal of Higher Education, 62(4), 394-406.

Tamanaha, B. Z. (2013). Is law school worth the cost? Journal of Legal Education, 63, 173-188.

United States Census Bureau. (2014). QuickFacts Beta. Retrieved from http://quickfacts.census.gov/qfd/states/00000.html

$\mathrm{Xu}, \mathrm{Y}$. (2013). Career outcomes of STEM and non-STEM college graduates: Persistence in majored-field and influential factors in career choices. Research in Higher Education. 54(3), 349-382.

$\mathrm{Xu}, \mathrm{Y}$. (2015). Focusing on women in STEM: A longitudinal examination of gender-based earning gap of college graduates. The Journal of Higher Education, 86 (4), 489-523.

Table 1. Descriptive information by gender and racial background (weighted samples).

\begin{tabular}{|c|c|c|c|c|}
\hline & \multicolumn{2}{|c|}{ Male } & \multicolumn{2}{|c|}{ Female } \\
\hline & White & Minorities & White & Minorities \\
\hline Wave 1 & $n=1905$ & $n=379$ & $n=1589$ & $n=408$ \\
\hline Law school loan & $\$ 58,248$ & $\$ 59,242$ & $\$ 59,792$ & $\$ 63,085$ \\
\hline Annual income & $\$ 86,241$ & $\$ 90,225$ & $\$ 76,653$ & $\$ 80,412$ \\
\hline mean (median) & $(\$ 75,000)$ & $(\$ 76,142)$ & $(\$ 62,500)$ & $(\$ 65,000)$ \\
\hline Law school ranking & 4.66 & 4.76 & 4.68 & 4.84 \\
\hline Total job offers (private offers) & $2.82(1.92)$ & $2.70(1.73)$ & $2.46(1.67)$ & $2.66(1.69)$ \\
\hline Practicing lawyer & $89 \%$ & $89 \%$ & $84 \%$ & $86 \%$ \\
\hline Satisfaction w/ legal career & 3.96 & 4.07 & 3.85 & 3.89 \\
\hline Wave 2 & $n=1,665$ & $n=335$ & $n=1,328$ & $n=354$ \\
\hline No. of informal mentors & 2.55 & 2.33 & 2.44 & 2.28 \\
\hline Practicing lawyer & $85 \%$ & $84 \%$ & $73 \%$ & $77 \%$ \\
\hline Already partnered & $11 \%$ & $7 \%$ & $8 \%$ & $4 \%$ \\
\hline Satisfaction w/ legal career & 3.91 & 4.00 & 3.79 & 3.86 \\
\hline Total annual income full-time & $\$ 130,872$ & $\$ 125,301$ & $\$ 100,618$ & $\$ 103,758$ \\
\hline employed (median) & $(\$ 105,000)$ & $(\$ 110,000)$ & $(\$ 86,358)$ & $(\$ 90,000)$ \\
\hline Wave 3 & $\mathrm{~N}=\mathbf{1 , 3 1 7}$ & $N=288$ & $\mathrm{~N}=\mathbf{1 , 0 2 5}$ & $\mathbf{N}=\mathbf{3 1 6}$ \\
\hline Married/partnered & $85 \%$ & $67 \%$ & $79 \%$ & $66 \%$ \\
\hline No. of children & 1.65 & 1.14 & 1.29 & 0.87 \\
\hline Social participation & .32 & .27 & .32 & .35 \\
\hline Law school ranking & 2.8 & 3.0 & 2.8 & 3.0 \\
\hline Practicing lawyer & $80 \%$ & $81 \%$ & $73 \%$ & $74 \%$ \\
\hline Already partnered (solo) & $30 \%(9 \%)$ & $17 \%(11 \%)$ & $18 \%(9 \%)$ & $14 \%(8 \%)$ \\
\hline Satisfaction w/ legal career & 3.91 & 3.93 & 3.86 & 3.89 \\
\hline Total income (median) & 194,136 & 196,576 & $\$ 135,758$ & $\$ 142,544$ \\
\hline & $(135,000)$ & $(125,000)$ & $(105,000)$ & $(\$ 109,709)$ \\
\hline
\end{tabular}


Table 2. Regression models of law career satisfaction

\begin{tabular}{|c|c|c|c|c|c|c|c|c|c|c|c|c|}
\hline & \multicolumn{3}{|c|}{$\begin{array}{c}\text { AJD Wave 1:2002 } \\
(n=3,821 ; \\
\left.\operatorname{model} R^{2}=.20\right) \\
\end{array}$} & \multicolumn{3}{|c|}{$\begin{array}{c}\text { AJD Wave 2: } 2007 \\
(n=2,297 ; \\
\left.\text { model } R^{2}=.18\right) \\
\end{array}$} & \multicolumn{3}{|c|}{$\begin{array}{c}\text { AJD Wave 3: 2012 } \\
\text { (White } n=1,629 ; \\
\text { model } R^{2}=.20 \text { ) } \\
\end{array}$} & \multicolumn{3}{|c|}{$\begin{array}{c}\text { AJD Wave 3: 2012 } \\
\text { (Minorities } n=290 ; \\
\text { model } R^{2}=.26 \text { ) } \\
\end{array}$} \\
\hline & $b$ & & $\beta$ & $b$ & & $\beta$ & $b$ & & $\beta$ & $b$ & & $\beta$ \\
\hline (Constant) & 6.332 & *** & & 5.878 & *** & & 6.202 & $* * *$ & & 5.887 & $* * *$ & \\
\hline Sex & -0.019 & & -0.009 & 0.073 & & 0.034 & -0.025 & & -0.012 & 0.149 & & 0.066 \\
\hline Marital status & -0.052 & & -0.025 & 0.004 & & 0.002 & -0.025 & & -0.009 & -0.270 & & -0.109 \\
\hline Number of minor & & & & & & & & & & & & \\
\hline dependents & 0.066 & $* * *$ & 0.056 & 0.028 & & 0.029 & 0.026 & & 0.031 & 0.019 & & 0.019 \\
\hline $\begin{array}{l}\text { Race (white vs. } \\
\text { minority) }\end{array}$ & -0.119 & $* *$ & -0.046 & -0.182 & $* * * *$ & -0.067 & & & & & & \\
\hline Parents' education & $\begin{array}{l}-0.119 \\
-0.013\end{array}$ & & $\begin{array}{l}-0.040 \\
-0.029\end{array}$ & $\begin{array}{c}-0.182 \\
-0.010\end{array}$ & & $\begin{array}{l}-0.00 \% \\
-0.021\end{array}$ & -0.004 & & -0.009 & -0.013 & & -0.029 \\
\hline Parents US born & 0.064 & $* * *$ & 0.061 & 0.011 & & 0.011 & 0.075 & $* * * *$ & 0.067 & -0.036 & & -0.029 \\
\hline $\begin{array}{l}\text { Participation in social } \\
\text { organizations in law }\end{array}$ & & & & & & & & & & & & \\
\hline school & 0.024 & ** & 0.045 & 0.018 & & 0.032 & 0.003 & & 0.007 & 0.009 & & 0.017 \\
\hline Law school ranking & -0.055 & $* * *$ & -0.064 & -0.046 & ** & -0.050 & -0.047 & & -0.052 & -0.043 & & -0.045 \\
\hline $\begin{array}{l}\text { Importance of past } \\
\text { legal experience in } \\
\text { obtaining } 1^{\text {st }} \text { job }\end{array}$ & 0.016 & & 0.015 & & & & & & & & & \\
\hline Social participation & & & & -0.281 & $* * *$ & -0.078 & 0.071 & & 0.016 & 0.571 & $* *$ & 0.126 \\
\hline No. of mentors & & & & 0.061 & $* * *$ & 0.097 & 0.054 & $* * *$ & 0.095 & 0.086 & * & 0.144 \\
\hline $\begin{array}{l}\text { No. } \\
\text { partner/managers of }\end{array}$ & & & & & & & & & & & & \\
\hline mentors & & & & -0.026 & & -0.038 & & & & & & \\
\hline $\begin{array}{l}\text { Mentor } \begin{array}{c}\text { provided } \\
\text { supports }\end{array} \text { within the }\end{array}$ & & & & & & & & & & & & \\
\hline organization & & & & & & & 0.039 & & 0.032 & -0.013 & & -0.010 \\
\hline $\begin{array}{l}\text { Mentor provided } \\
\text { supports external to the }\end{array}$ & & & & & & & & & & & & \\
\hline organization & & & & & & & 0.011 & & 0.011 & 0.038 & & 0.036 \\
\hline $\begin{array}{l}\text { Law } \\
\text { financed by personal }\end{array}$ & & & & & & & & & & & & \\
\hline resources $(\%)$ & -0.000 & & -0.013 & -0.001 & & -0.031 & 0.001 & & 0.020 & -0.002 & & -0.056 \\
\hline Total law education & & & & & & & & & & & & \\
\hline $\begin{array}{l}\text { debt } \\
\text { Experienced }\end{array}$ & -0.000 & & -0.025 & -0.000 & $* * *$ & -0.097 & -0.000 & & -0.055 & -0.000 & & -0.076 \\
\hline discrimination at work & -0.229 & ** & -0.046 & -0.081 & & -0.014 & -0.466 & $* * *$ & -0.083 & -0.024 & & -0.005 \\
\hline Employment Status & 0.116 & & 0.018 & -0.120 & & -0.040 & 0.242 & $* * *$ & 0.089 & 0.090 & & 0.031 \\
\hline Practicing Lawyer & -0.068 & & -0.020 & 0.196 & $* * *$ & 0.069 & 0.114 & & 0.045 & 0.492 & $* * *$ & 0.180 \\
\hline Job Satisfaction & 0.426 & $* * *$ & 0.417 & 0.390 & $* * *$ & 0.391 & 0.369 & $* * *$ & 0.358 & 0.394 & $* * *$ & 0.366 \\
\hline $\begin{array}{l}\text { No. of job offers from } \\
\text { public organizations } \\
\text { No. of job offers from }\end{array}$ & 0.033 & & 0.029 & & & & & & & & & \\
\hline private organizations & -0.020 & & -0.026 & & & & & & & & & \\
\hline $\begin{array}{l}\text { Annual income (log- } \\
\text { transformed) }\end{array}$ & 0.163 & $* * *$ & 0.083 & 0.188 & $* * *$ & 0.107 & 0.159 & $* * * *$ & 0.113 & 0.107 & & 0.069 \\
\hline
\end{tabular}

